University of Nebraska - Lincoln

DigitalCommons@University of Nebraska - Lincoln

2001

\title{
Dissimilatory bacterial reduction of Al-substituted goethite in subsurface sediments
}

\author{
Ravi K. Kukkadapu \\ Pacific Northwest National Laboratory, ravi.kukkadapu@pnl.gov \\ John M. Zachara \\ Pacific Northwest National Laboratory \\ Steven C. Smith \\ Pacific Northwest National Laboratory \\ James K. Fredrickson \\ Pacific Northwest National Laboratory, jim.fredrickson@pnl.gov \\ Chongxuan Liu \\ Pacific Northwest National Laboratory
}

Follow this and additional works at: https://digitalcommons.unl.edu/usdoepub

Part of the Bioresource and Agricultural Engineering Commons

Kukkadapu, Ravi K.; Zachara, John M.; Smith, Steven C.; Fredrickson, James K.; and Liu, Chongxuan, "Dissimilatory bacterial reduction of Al-substituted goethite in subsurface sediments" (2001). US Department of Energy Publications. 153.

https://digitalcommons.unl.edu/usdoepub/153

This Article is brought to you for free and open access by the U.S. Department of Energy at DigitalCommons@University of Nebraska - Lincoln. It has been accepted for inclusion in US Department of Energy Publications by an authorized administrator of DigitalCommons@University of Nebraska - Lincoln. 


\title{
PII S0016-7037(01)00656-1
}

\section{Dissimilatory bacterial reduction of Al-substituted goethite in subsurface sediments}

\author{
Ravi K. Kukkadapu*, John M. Zachara, Steven C. Smith, James K. Fredrickson, and Chongxuan Liu \\ Pacific Northwest National Laboratory, Richland, WA 99352, USA
}

(Received December 12, 2000; accepted in revised form April 12, 2001)

\begin{abstract}
The microbiologic reduction of a 0.2 to $2.0 \mu \mathrm{m}$ size fraction of an Atlantic coastal plain sediment (Eatontown) was investigated using a dissimilatory Fe(III)-reducing bacterium (Shewanella putrefaciens, strain $\mathrm{CN} 32)$ to evaluate mineralogic controls on the rate and extent of $\mathrm{Fe}(\mathrm{III})$ reduction and the resulting distribution of biogenic Fe(II). Mössbauer spectroscopy and X-ray diffraction (XRD) were used to show that the sedimentary $\mathrm{Fe}(\mathrm{III})$ oxide was Al-substituted goethite $(13-17 \% \mathrm{Al})$ that existed as 1 - to 5- $\mu \mathrm{m}$ aggregates of indistinct morphology. Bioreduction experiments were performed in two buffers $\left[\mathrm{HCO}_{3}^{-} ; 1,4\right.$-piperazinediethansulfonic acid (PIPES)] both without and with 2,6-anthraquinone disulfonate (AQDS) as an electron shuttle. The production of biogenic $\mathrm{Fe}(\mathrm{II})$ and the distribution of $\mathrm{Al}$ (aqueous and sorbed) were followed over time, as was the formation of $\mathrm{Fe}(\mathrm{II})$ biominerals and physical/chemical changes to the goethite.

The extent of reduction was comparable in both buffers. The reducibility (rate and extent) was enhanced by AQDS; 9\% of dithionite-citrate-bicarbonate (DCB) extractable Fe(III) was reduced without AQDS whereas $15 \%$ was reduced in the presence of AQDS. XRD and Mössbauer spectroscopy were used to monitor the disposition of biogenic Fe(II) and changes to the Al-goethite. Fe(II) biomineralization was not evident by XRD. Biomineralization was observed by Mössbauer when sorbed Fe(II) concentrations exceeded a threshold value. The biomineralization products displayed Mössbauer spectra consistent with siderite $\mathrm{FeCO}_{3}\left(\mathrm{HCO}_{3}^{-}\right.$ buffer only) and green rust $\left[\mathrm{Fe}_{(6-\mathrm{x})}^{\mathrm{II}} \mathrm{Fe}_{\mathrm{x}}^{\mathrm{III}}(\mathrm{OH})_{12}\right]^{\mathrm{x}+}\left[\left(\mathrm{A}^{2-}\right)_{\mathrm{x} / 2} \cdot y \mathrm{H}_{2} \mathrm{O}\right]^{\mathrm{x}-}$. Adsorption of biogenic $\mathrm{Fe}(\mathrm{II})$ to accessory mineral phases (e.g., kaolinite) and bacterial surfaces appeared to limit biomineralization. $\mathrm{Al}$ evolved during reduction was sorbed, and extractable Al increased with reduction. XRD analysis indicated that neither crystallite size or the $\mathrm{Al}$ content of the goethite was affected by bacterial reduction, i.e., $\mathrm{Al}$ release was congruent with Fe(II). Copyright (C) 2001 Elsevier Science Ltd
\end{abstract}

\section{INTRODUCTION}

Valence transformations between $\mathrm{Fe}(\mathrm{II})$ and $\mathrm{Fe}(\mathrm{III})$ are central to the iron biogeochemical cycle in sediments and subsurface environments (Sulzberger et al., 1989; Chapelle, 1993). $\mathrm{Fe}(\mathrm{III})$ oxides are ubiquitous secondary mineralization products (Cornell and Schwertmann, 1996) and function as the primary redox buffering solid phase in sediments and subsurface systems (Heron et al., 1994). To a large degree, the reduction of $\mathrm{Fe}(\mathrm{III})$ oxides and the consumption of sediment oxidative equivalents are driven by dissimilative bacterial reduction. Consequently, defining the interrelationships between dissimilatory $\mathrm{Fe}(\mathrm{III})$ reduction, $\mathrm{Fe}(\mathrm{II} / \mathrm{III})$ mineralogy, and redox status is critical to understanding the geochemistry of redox interfaces and transition zones, and anoxic subsurface systems.

Amorphous and crystalline Fe(III) oxides are utilized as electron acceptors by dissimilatory Fe-reducing bacteria (DIRB) (Lovley and Phillips, 1986; Arnold et al., 1986; Roden and Zachara, 1996; Fredrickson et al., 1998; Zachara et al., 1998). S. alga and other facultative Shewanella strains can grow, albeit slowly, using ferrihydrite and goethite as sole electron acceptors (Roden and Zachara, 1996). Synthetic goethite is resistant to bacterial reduction and, in general, is incompletely reduced in presence of excess electron donor and large cell populations (e.g., $>10^{8}$ cells $/ \mathrm{mL}$ ). Low solubility, saturation of the residual oxide and bacterial surfaces with biogenic $\mathrm{Fe}(\mathrm{II})$, free energy availability, and complex physio-

* Author to whom correspondence should be addressed. Pacific Northwest National Laboratory, MSIN K8-96, P.O. Box 999, Richland, WA 99352. (E-mail: ravi.kukkadapu@pnl.gov). logic factors apparently control the rate and extent of reduction (Roden and Zachara, 1996; Urrutia et al., 1998; Zachara et al., 1998; Liu et al., 2001). Aqueous and solid-phase ligands that withdraw biogenic Fe(II) from the oxide and bacterial surfaces tend to increase the extent of goethite reduction (Urrutia et al., 1998, 1999), presumably by reducing the surface saturation of $\mathrm{Fe}(\mathrm{II})$.

Although not well studied, natural crystalline Fe(III) oxides, including both goethite and hematite, appear more reducible than those synthesized in the laboratory (Roden and Zachara, 1996; Zachara et al., 1998). The reasons for this observation have not been confirmed but isomorphous substitution of $\mathrm{Fe}(\mathrm{III})$ by other metals (e.g., $\mathrm{Al}(\mathrm{III})$ ), and larger crystallite disorder, surface roughness, and surface area of natural Fe(III) oxides may be important. Soil and geologic iron oxides show considerable substitution by other cations (Schwertmann, 1985). The substitution of $\mathrm{Al}(\mathrm{III})$ for $\mathrm{Fe}(\mathrm{III})$ has been well documented in soil goethites, and can reach $\sim 33 \mathrm{~mol} \%$ [or $\mathrm{Al} /(\mathrm{Al}+\mathrm{Fe})$ of 0.33$]$. The $\mathrm{Al}$ content of soil goethites varies with crystallite size; increasing with a decrease in size (Norrish and Taylor, 1961). Acid and reductive dissolution rates change systematically with increasing Al substitution (Schwertmann, 1984; Torrent et al., 1987). The reducibility of goethite by an acid-producing fermentative bacterium was observed to be reduced by Al substitution (Bousserrhine et al., 1999). Additionally, the presence of accessory mineral phases that may adsorb and sequester biogenic Fe(II) may enhance reduction by decreasing surface passivation of the residual Fe(III) oxide.

This communication investigates the dissimilatory bacterial reduction of natural Al-substituted goethite in Pleistocene-age 


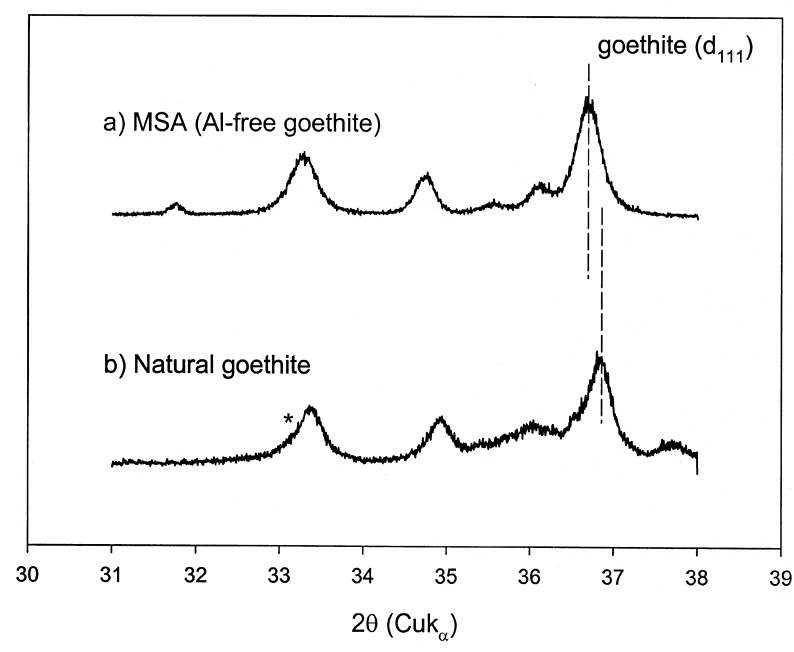

Fig. 1. Powder XRD patterns of (a) MSA goethite and (b) Eatontown goethite $\left(0.2-2.0 \mu \mathrm{m}\right.$ size fraction). $\mathrm{d}_{111}$ values were derived from fits.

subsurface sediments. Ferrigenic groundwaters are often found in such sediments of the Atlantic Coastal Plain of the United States (e.g., Lovley et al., 1990) and their formation is likely of bacterial origin. The natural goethite and its bioreduction products were characterized by various techniques including chemical extractions, X-ray diffraction (XRD), and by ${ }^{57} \mathrm{Fe}$ transmission Mössbauer spectroscopy. Our overall objective was to identify characteristics of the natural goethite and the accessory mineralogy that controlled the extent of reduction and resulting $\mathrm{Fe}(\mathrm{II})$ biomineralization.

\section{MATERIAL AND METHODS}

\subsection{The Eatontown Sediment}

Unconsolidated, sand textured, Pleistocene-age, Atlantic Coastal Plain sediment was collected in Eatontown, New Jersey. The sampling depth was approximately $3 \mathrm{~m}$ below the surface; overriding surface soils were characterized as Ultisols. The sediments were beach deposits and were dominated by sand-textured quartz grains. This particular sediment represented a goethite-enriched zone of approximately $0.5 \mathrm{~m}$ that underlied an identically enriched layer in hematite. The hematiteenriched sediment has been previously described (Zachara et al., 1998). In the goethite-enriched band, crystalline Fe(III) oxides exist as grain coatings, discrete microprecipitates, and intergrain cements imparting a distinct yellowish-orange coloration to the sediment similar to that described by Schwertmann and Cornell (1991) (Fig. 1, Plate 111 of the reference). Kaolinite, muscovite, and quartz existed as primary accessory mineral phases.

Dispersible coatings were removed from the $<2 \mathrm{~mm}$ size fraction by shaking in $1 \mathrm{mM} \mathrm{NaClO}_{4}(1: 2 \mathrm{wt}: \mathrm{wt})$ three times. The $\mathrm{pH}$ of the "bulk dispersate" suspension was adjusted to 8.3 using $\mathrm{NaOH}$. A 0.2 to $2 \mu \mathrm{m}$ size fraction was obtained using Stokes' law calculation of settling time. The suspension was dialyzed against deionized water, lyophilized, and characterized.

Extractable $\mathrm{Fe}(\mathrm{III})$ was determined using three techniques. Hydroxylamine hydrochloride (Chao and Zhou, 1983) was used for the extraction of amorphous iron oxyhydroxides and reducible manganese oxides. Ammonium oxalate (Schwertmann, 1964; Fey and LeRoux, 1977) was used for the removal of amorphous aluminosilicates as well as poorly crystalline forms of iron oxides. Dithionite-citrate-bicarbonate (DCB) (Mehra and Jackson, 1960) was used for the complete extraction of reducible $\mathrm{Fe}(\mathrm{III})$ oxides.

\subsection{Bacteria and Media}

Shewanella putrefaciens, strain CN32, was provided courtesy of Dr. David Boone (Portland State University, Portland, Oregon). The strain was cultured as described previously (Zachara et al., 1998). Cells were harvested at mid to late lag phase by centrifugation from tryptic soy broth cultures, washed with sterile buffer $\left[\mathrm{O}_{2}\right.$-free $\mathrm{NaHCO}_{3}$ or $1,4-$ piperazinediethanesulfonic acid (PIPES)], and resuspended in buffers. The nongrowth media were buffered either with $30 \mathrm{mM} \mathrm{NaHCO}$ or 30 $\mathrm{mM}$ PIPES. Sodium lactate $(30 \mathrm{mM})$ was added as the electron donor and, in some treatments, filter-sterilized $(0.2 \mu \mathrm{m})$ anthraquinone-2,6disulfonate (AQDS; Sigma Chemical Co.; $0.10 \mathrm{mM}$ ) was added separately. Other media components included (in $\mathrm{mM}$ ): $\mathrm{NH}_{4} \mathrm{Cl}(28), \mathrm{KCl}$ (1.34), $\mathrm{CaCl}_{2} \cdot 2 \mathrm{H}_{2} \mathrm{O}(0.68)$, and $\mathrm{NaClO}_{4}(50)$. Each media solution was adjusted to $\mathrm{pH} 7.0$ with $\mathrm{NaOH}$ and filter sterilized before use.

Bioreduction experiments were carried out using the 0.2 to $2 \mu \mathrm{m}$ size fraction of the sediment because of its sizable $\mathrm{Fe}$ (III) oxide content. Five $\mathrm{mL}$ of $100 \mathrm{mM} \mathrm{Fe}$ (III) (based on DCB extraction) and $4 \mathrm{~mL}$ of the desired microbial medium were added to headspace vials. To reduce the $\mathrm{O}_{2}$ present in the system, a stream of $\mathrm{O}_{2}$-free $\mathrm{N}_{2}: \mathrm{CO}_{2}(80: 20)$ or $\mathrm{N}_{2}$ for $\mathrm{HCO}_{3}^{-}$or PIPES buffered media, respectively, was passed over the suspension in each vial for $5 \mathrm{~min}$ and sealed with butyl rubber stoppers. The cell culture $\left(1 \mathrm{~mL}, 10^{9}\right.$ cells $\left.\mathrm{mL}^{-1}\right)$ was aseptically and anoxically added. The final $\mathrm{Fe}$ (III) concentration of the suspensions was $50 \mathrm{mM}$. Vials were incubated in the dark at $30^{\circ} \mathrm{C}$ and agitated (horizontally) at $100 \mathrm{rpm}$ until sampled. Each treatment and sampling event was replicated three times and separate tubes were sacrificed at each time-point for analyses. Abiotic controls consisted of suspension that received 1 $\mathrm{mL}$ of sterile, anaerobic buffer in place of a CN32 cell suspension.

\subsection{Analyses}

Replicate vials were removed from the incubator and transferred to an anaerobic $\left(\mathrm{N}_{2}: \mathrm{H}_{2}, 95: 5\right)$ chamber at select times. Each suspension was vortex-mixed for approximately $1 \mathrm{~min}$ before sampling. Four $\mathrm{mL}$ of suspension was transferred into a $10-\mathrm{mL}$ plastic syringe fitted with $0.2-\mu \mathrm{m}$ filter unit. Approximately $1 \mathrm{~mL}$ (after discarding the first 20 drops of filtrate) of the filtrate was combined with $1 \mathrm{~mL}$ of anoxic $1 \mathrm{~N}$ $\mathrm{HCl}$ in a polystyrene tube. This fraction was considered to be the soluble fraction and was analyzed for $\mathrm{Fe}(\mathrm{II})$ and $\mathrm{Al}$. The filtration step was shown effective in the removal of both fine-grained Fe(III) oxides and biogenic mineral products (Fredrickson et al., 1998). In another aliquot, $\mathrm{pH}$ was measured under anaerobic conditions using a combination $\mathrm{pH}$ electrode (Orion $\mathrm{pH}$ meter/Microelectrode, Inc.). HCl-extractable components were obtained by placing $0.2 \mathrm{~mL}$ of suspension into a polystyrene tube containing $3.8 \mathrm{~mL}$ of $0.53 \mathrm{~mol} / \mathrm{L} \mathrm{HCl}$. This extraction is termed $0.5 \mathrm{~N} \mathrm{HCl}$ extraction. Sodium acetate $(\mathrm{NaOAc})$ extractable components were obtained by placing $0.2 \mathrm{~mL}$ of suspension into a tube containing $3.8 \mathrm{~mL}$ of $1.05 \mathrm{~mol} / \mathrm{L} \mathrm{NaOAc}$ adjusted to $\mathrm{pH} 5$ with acetic acid. The $\mathrm{HCl}$ extractions were equilibrated for $1 \mathrm{~d}$ and the $\mathrm{NaOAc}$ extract equilibrated for $7 \mathrm{~d}$ at $30^{\circ} \mathrm{C}$ and $100 \mathrm{rpm}$ (Heron et al., 1994). The $\mathrm{HCl}$ and $\mathrm{NaOAc}$ extractions were filtered as described previously. To stabilize the $\mathrm{Fe}(\mathrm{II}) / \mathrm{Fe}(\mathrm{III})$ in the $\mathrm{NaOAc}$ extracts, $2 \mathrm{~mL}$ of filtrate were combined with $2 \mathrm{~mL}$ of anoxic $1 \mathrm{~N}$ Ultrex $\mathrm{HCl}$. The $\mathrm{Fe}(\mathrm{II})$ concentration in the extracts was determined using the ferrozine assay (Stookey, 1970). Total Fe [Fe(II)+Fe(III)] was determined by adding an aliquot of $10 \% \mathrm{NH}_{2} \mathrm{OH} \cdot \mathrm{HCl}$ to the sample, waiting $24 \mathrm{~h}$ for complete reduction of $\mathrm{Fe}$ (III) to $\mathrm{Fe}(\mathrm{II})$, then remeasuring color intensity by the ferrozine assay. Total $\mathrm{Fe}$ and $\mathrm{Al}$ concentrations were determined in all the extractions by a Hewlett Packard 4500 inductively coupled plasma-mass spectrograph (ICP-MS).

\subsection{Electron Microscopy and Powder X-ray Diffraction}

A Leo 982 FEG scanning electron microscope (SEM) fitted with back-scatter and secondary electron detectors was used for secondary electron imaging of the natural Fe(III) oxides. The sample preparation procedure has been described previously (Zachara et al., 1998). Powder XRD patterns were obtained using a Philips PW3040/00 X'Pert MPD system and $\mathrm{Cu}$ anode. The routine operating power was 2,000 W (40 $\mathrm{kV}, 50 \mathrm{~mA}$ ). The $\mathrm{d}_{111}$ spacings and mean coherence distances (MCD) were obtained by fitting the XRD patterns using the JADE+, V5 
(Materials Data Inc., Livermore, California) data analysis software package. Low-background quartz XRD slides were used. Powder samples were tightly packed into the well (1/4-inch diameter) of the slides for analysis. Bioreduced specimens were filtered through a $0.2-\mu \mathrm{m}$ nylon filter and washed with 1 to $2 \mathrm{~mL}$ of acetone immediately before analysis to obtain "dry" powder samples.

\section{5. ${ }^{57}$ Fe Mössbauer Spectroscopy}

Randomly orientated absorbers were prepared by mixing $100 \mathrm{mg}$ of unreduced sediment $\left(6 \mathrm{mg}\right.$ of $\left.\mathrm{Fe} / \mathrm{cm}^{2}\right)$ with petroleum jelly in a 0.5 -inch thick and 0.5-inch i.d. Cu holder sealed at one end with clear scotch tape. The sample space was filled with petroleum jelly and the ends sealed with tape. An oxygen impermeable polymer stable at $4.2 \mathrm{~K}$ (Kapak Corporation, Minneapolis, MN) was used for low-temperature analyses. The reduced samples were handled under anaerobic atmosphere in an environmental chamber. Approximately $6.8 \mathrm{~cm}^{3}$ of the composited reduced suspension was filtered and washed with acetone as previously described to obtain a "dry" powder. The powders were then mixed with petroleum jelly under anoxic conditions, sealed with tape or polymer, and kept in an anoxic chamber until analysis.

Room-temperature Mössbauer spectra were obtained as described by Dong et al. (2000). Cryogenic measurements were carried out using a top-loading Janis exchange-gas cryostat with the source and drive assembly at room temperature. The resulting spectra were evaluated with the Recoil program (University of Ottawa, Canada) using the Lorentzian method.

\section{RESULTS}

\subsection{Properties of the Fe(III) Oxide Fraction}

The 0.2 to $2.0 \mu \mathrm{m}$ sediment fraction contained $5.5 \mathrm{mmol}$ or $0.31 \mathrm{~g}$ of $\mathrm{Fe}$ (III) per gram of sediment as determined by DCB extraction. Only a small amount $(<0.5 \%)$ of the DCB extractable $\mathrm{Fe}(\mathrm{III})$ could be extracted by $\mathrm{NH}_{2} \mathrm{OH} \cdot \mathrm{HCl}$ or ammonium oxalate, indicating that the $\mathrm{Fe}(\mathrm{III})$ oxides were crystalline.

The sediment fraction contained kaolinite, muscovite, quartz, and goethite as determined by XRD (not shown). Both kaolinite and muscovite dominated the spectrum. The diffractogram region of $32^{\circ}$ to $38^{\circ} 2 \theta$ (Fig. 1) was used to further characterize the $\mathrm{Fe}(\mathrm{III})$ oxide fraction because the most intense hematite reflection $\left(\mathrm{d}_{104}\right)$ appears at $33.2^{\circ} 2 \theta$ and changes in the $\mathrm{d}_{111}$ of goethite, which is sensitive to foreign element substitution, can be monitored. The sample exhibited small hematite shoulder peak at $33.2^{\circ} 2 \theta$ (asterisk in Fig. 1). A diffractogram of synthetic, Al-free goethite medium surface area (MSA) was used as a reference to which the natural goethite was compared (Fig. $1)$. The $d_{111}$ spacing of the natural goethite was shifted to higher $2 \theta$ values than that of MSA goethite $(0.2448 \mathrm{~nm}$ vs. $0.2435 \mathrm{~nm})$.

The natural Fe(III) oxide exhibited a $\mathrm{MCD}_{111}(24 \mathrm{~nm})$ comparable to the MSA goethite $(21 \mathrm{~nm})$. However, the natural and synthetic goethites differed in morphology (Fig. 2). The sedimentary goethite appeared as 1 - to 5- $\mu \mathrm{m}$ aggregates of indistinct particles that contrasted with the acicular, lath morphology of MSA goethite. The $\mathrm{MCD}_{111}$ value indicated that the sedimentary goethite particles were composed of small crystallites that were not well resolved by microscopy. The MSA goethite existed as well-formed acicular crystallite bundles (nominally containing 3-8 individual crystals) of approximately 200 to $400 \mathrm{~nm}$ length and 50 to $150 \mathrm{~nm}$ width (Zachara et al., 1998; Zachara et al., 1999).

An intense asymmetric doublet and low-intensity sextets dominated the RT Mössbauer spectrum (Fig. 3a) whereas an
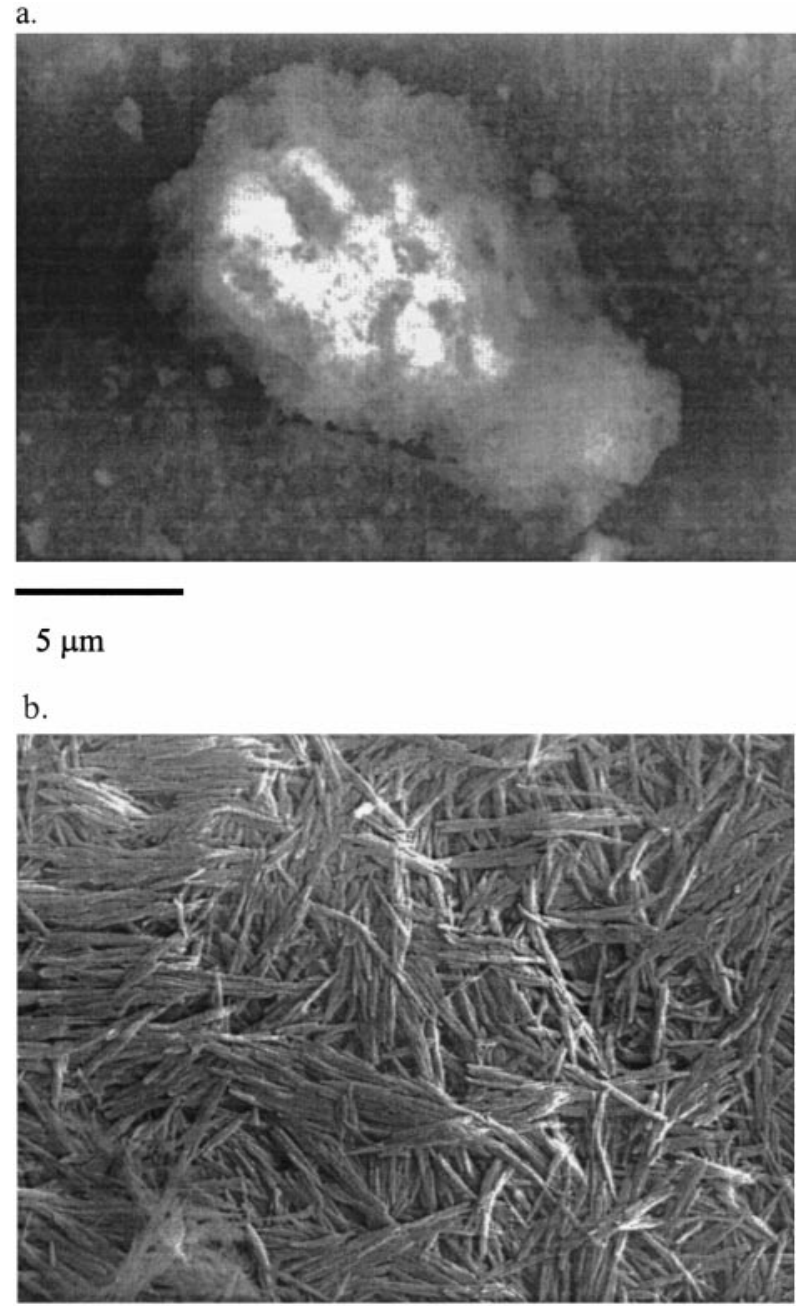

\section{$2 \mu \mathrm{m}$}

Fig. 2. SEM images of (a) 0.2 to $2.0 \mu \mathrm{m}$ fraction and (b) MSA goethite.

intense sextet dominated the $4.2 \mathrm{~K}$ spectrum (Fig. $3 \mathrm{~b}$ ). A minor sextet with slightly higher $B_{\mathrm{hf}}$ contributed to the sextet spectrum. This contribution was evident as shoulders at the far ends of the spectrum.

The $4.2 \mathrm{~K}$ spectrum was fitted with two sextets (A and B) using a Lorentzian model. The fit pattern was included in Figure $3 \mathrm{~b}$. The hyperfine parameters for sextet A (intense; $96 \%$ area) were: $\delta=0.475 \pm 0.001 \mathrm{~mm} / \mathrm{s}, \varepsilon=-0.131 \pm 0.001$ $\mathrm{mm} / \mathrm{s}$, and $B_{\mathrm{hf}}=49.56 \pm 0.01 \mathrm{~T}$, and those for sextet B (minor, $4 \%$ area) were: $\delta=0.413 \pm 0.009 \varepsilon=-0.047 \pm 0.009$ and $B_{\mathrm{hf}}=53.02 \mathrm{~T}$.

\subsection{Bioreduction Experiments}

\subsubsection{Natural goethite}

Bioreduction experiments were performed in two buffers (PIPES, $\mathrm{HCO}_{3}^{-}$) both without and with AQDS, an electron shuttle that enhances solid-phase Fe(III) reduction (Zachara et 
a) RT spectrum

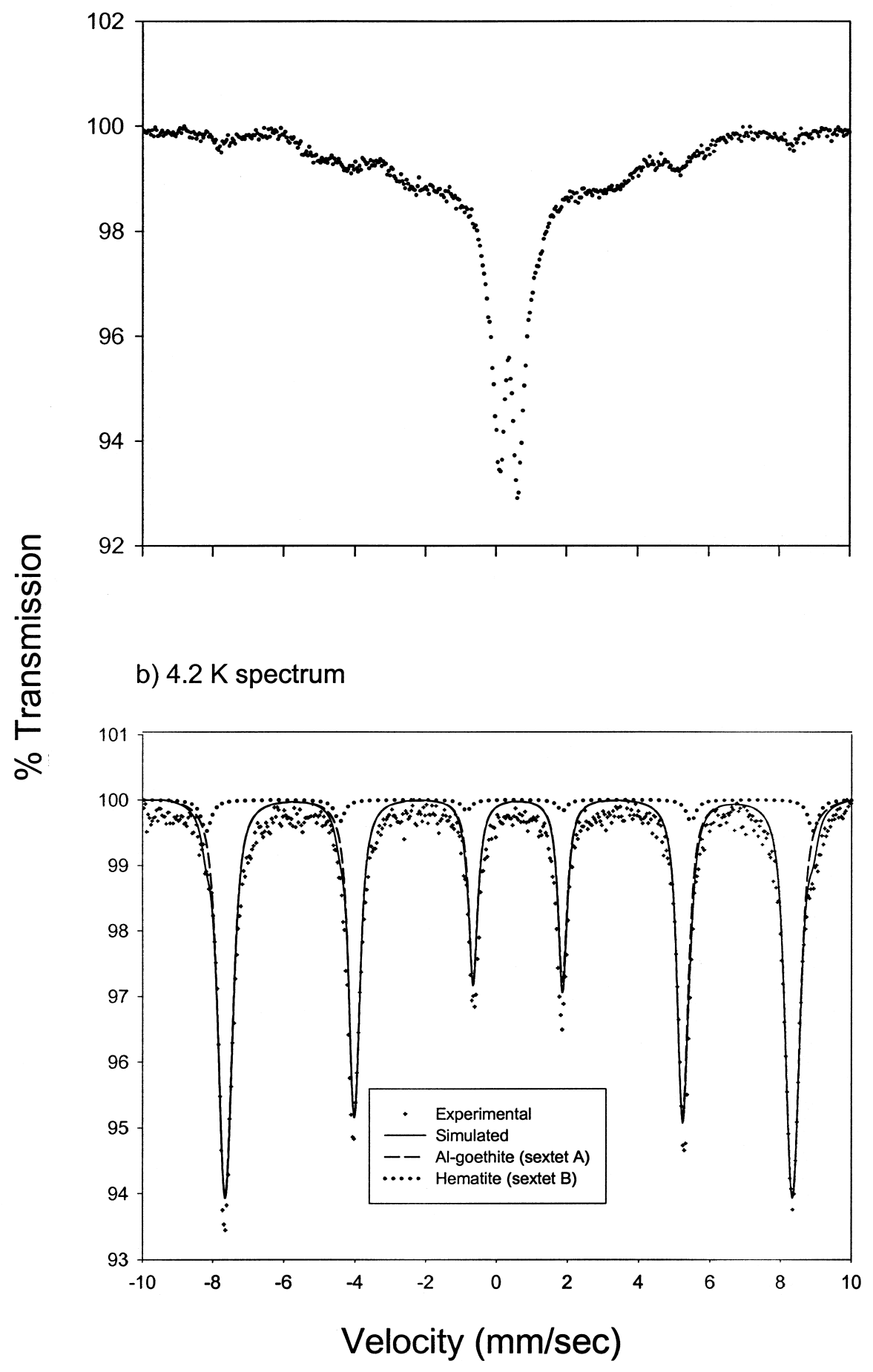

Fig. 3. (a) Room-temperature Mössbauer spectrum of the 0.2 to $2 \mu \mathrm{m}$ fraction and (b) experimental and simulated spectra of the 0.2 to $2 \mu \mathrm{m}$ fraction measured at $4.2 \mathrm{~K}$.

al., 1998). The two buffers were used because they tend to promote the formation of different biomineralization products (Fredrickson et al., 1998) when ferrihydrite is the electron acceptor.

In the absence of AQDS, bioreduction was initially rapid, followed by slowing or cessation after approximately $8 \mathrm{~d}$ of incubation (Fig. 4a,c). The overall reduction extent (determined by $0.5 \mathrm{~N} \mathrm{HCl}$ extraction) was comparable in both buffers, reaching $9 \%(4.5 \mathrm{mM})$ of the $\mathrm{Fe}(\mathrm{III})$ oxide fraction extractable by DCB. Approximately 60 to $80 \%$ of the biogenic Fe(II) was sorbed, $\left(\mathrm{Fe}_{(\text {sorb) }}^{2+}\right)$, with the remaining $(20-40 \%)$ released to solution, $\mathrm{Fe}_{(\mathrm{aq})}^{2+}$. The release of $\mathrm{Fe}_{(\mathrm{aq})}^{2+}$ was retarded relative to 
a. PIPES

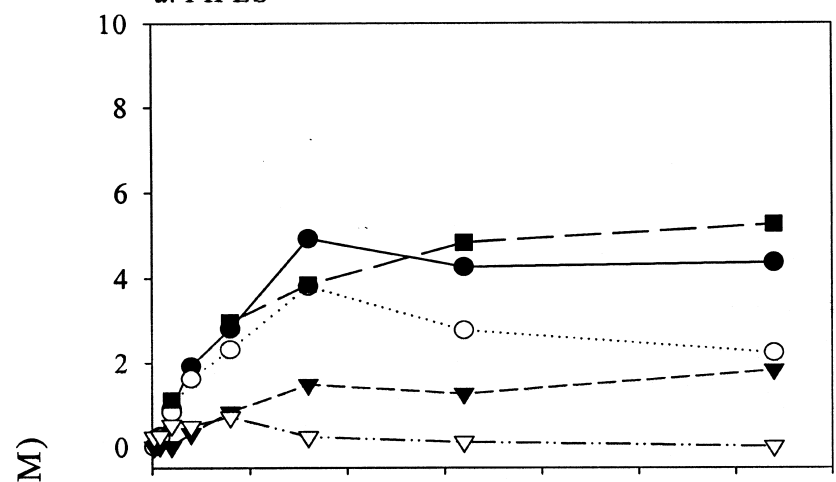

c. $\mathrm{HCO}_{3}{ }^{-}$

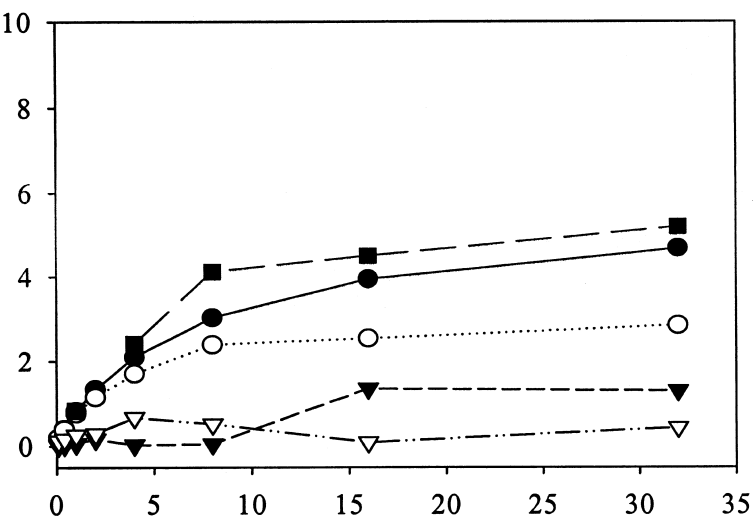

b. PIPES/AQDS

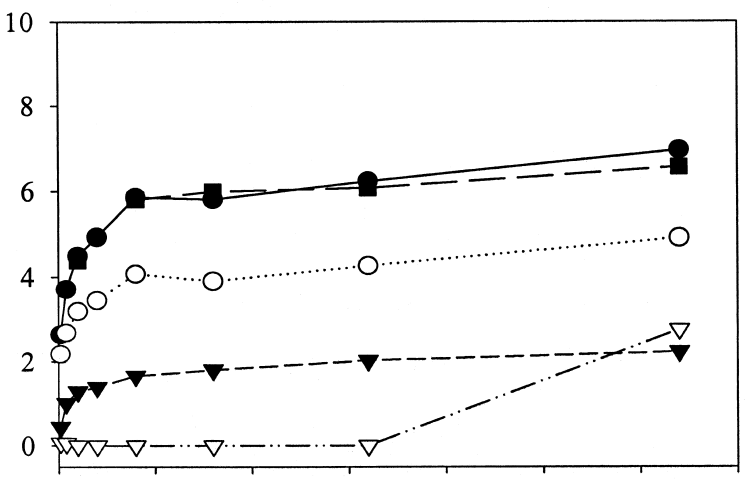

d. $\mathrm{HCO}_{3}-/ \mathrm{AQDS}$

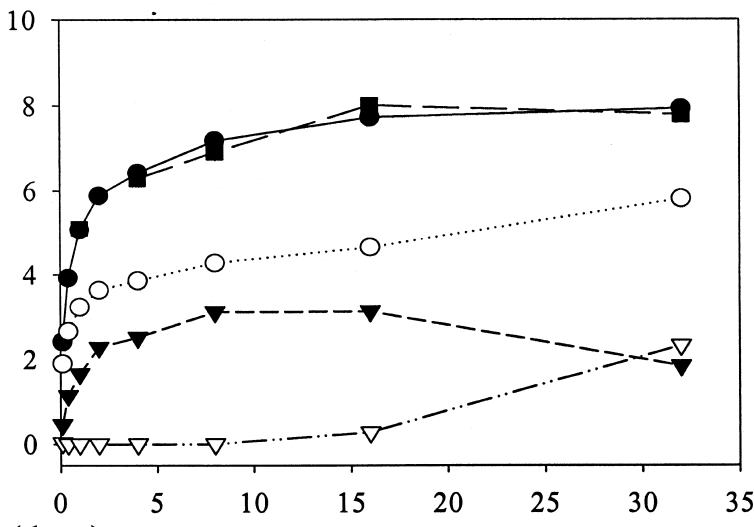

Time (days)

\begin{tabular}{|c|c|}
\hline 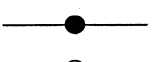 & $0.5 \mathrm{~N} \mathrm{HCl}$-extractable $\mathrm{Fe}_{\text {total }}$; includes $\mathrm{Fe}_{\text {aqueous }}$ \\
\hline$\cdots \cdots \cdots \cdots$ & Sorbed, $0.5 \mathrm{~N} \mathrm{HCl-extractable} \mathrm{Fe}_{\text {total }}$; excludes $\mathrm{Fe}_{\text {aqueous }}$ \\
\hline$---\boldsymbol{\nabla}--$ & Aqueous $\mathrm{Fe}(\mathrm{II})$, \\
\hline$-\cdots \rightarrow-\cdot \cdot-$ & $\mathrm{NaOAc}$-extractable $\mathrm{Fe}(\mathrm{II})$; excludes $\mathrm{Fe}_{\text {aqueous }}$ \\
\hline$-\rightarrow-$ & $0.5 \mathrm{~N} \mathrm{HCl}$-extractable Fe; determined by ICP-MS \\
\hline
\end{tabular}

Fig. 4. Extractable $\mathrm{Fe}(\mathrm{II})(0.5 \mathrm{~N} \mathrm{HCl}, \mathrm{NaOAc}), \mathrm{Fe}_{\text {(sorb) }}^{2+}, \mathrm{Fe}_{\text {(aq) }}^{2+}$, and $\mathrm{Fe}_{(\text {tot) }}$ (ICP-MS) in buffered 0.2 to $2.0 \mu \mathrm{m}$ Eatontown goethite suspension $\left(50 \mathrm{mM}\right.$ ) inoculated with $\mathrm{CN} 32$ in (a) PIPES, (b) PIPES/AQDS, (c) $\mathrm{HCO}_{3}^{-}$, and (d) $\mathrm{HCO}_{3}^{-} / \mathrm{AQDS}$.

the overall reduction rate, suggesting adsorption to cell material or residual mineral surfaces, and/or precipitation. The $\mathrm{pH} 4.5$ $\mathrm{NaOAc}$ extraction was used to remove exchangeable and reversibly adsorbed $\mathrm{Fe}(\mathrm{II})$ associated with the organism, the residual $\mathrm{Fe}$ (III) oxide, and accessory minerals such as kaolinite (e.g., Heron et al., 1994). The NaOAc extraction solubilized only a small amount of sorbed Fe(II), indicating that the bulk was strongly adsorbed or precipitated, or both.

AQDS enhanced both the rate and extent of bioreduction (Fig. 4b,d). Approximately 12 to $16 \%(6-8 \mathrm{mM})$ of the DCBextractable Fe(III) was reduced after $16 \mathrm{~d}$ incubation in PIPES and $\mathrm{HCO}_{3}^{-}$buffers. $\mathrm{Fe}_{(\text {aq) }}^{2+}$ accumulated more rapidly in presence of AQDS. Exchangeable $\mathrm{Fe}(\mathrm{II})$ ( $\mathrm{NaOAc}$ extractable) was low throughout the experiment, but increased at the last sampling point. Sorbed, non-NaOAc extractable Fe(II) was the largest pool of biogenic $\mathrm{Fe}(\mathrm{II})$.

The total $\mathrm{Fe}-\mathrm{HCl}$ data from all the reduction experiments was amenable to simple kinetic analyses. These were well fit by a first-order kinetic model $\{R=\mathrm{k}[$ available $\mathrm{Fe}(\mathrm{III})]\}$ where the rate constant $(\mathrm{k})$ and bioavailable $\mathrm{Fe}(\mathrm{III})$ ([Fe(III)]) were adjustable parameters. Both the initial rate $\left(R_{\mathrm{i}}\right)$ and the rate constant (k) indicated that reduction was approximately 1.5 times more rapid in PIPES than in $\mathrm{HCO}_{3}^{-}$buffer, and that AQDS accelerated these rates by approximately 10 -fold (Table 1 ).

Aqueous and extractable $\mathrm{Al}$ was measured to define the fate of Al liberated through the reductive dissolution of the natural goethite (Fig. 5). Aqueous Al concentrations were low and below detection $(0.1 \mu \mathrm{m})$ in all experiments. However, significant $\mathrm{Al}$ was measured in the $\mathrm{HCl}$ and $\mathrm{NaOAc}$ extractions. Both the initial and total concentrations of $\mathrm{Al}$ extracted by $0.5 \mathrm{~N} \mathrm{HCl}$ were higher in bioreduced samples containing AQDS.

Extractable and aqueous $\mathrm{Fe}$ and $\mathrm{Al}$ were measured in the controls to follow the effects of media, particularly AQDS, a redox-active compound. Small quantities of $\mathrm{Al}$ and $\mathrm{Fe},<0.5 \%$ of inoculated samples, were measured in the extractions. These data suggested that the media was unimportant in $\mathrm{Fe}$ and $\mathrm{Al}$ solubilization from the sediment. 
Table 1. Kinetic parameters.

\begin{tabular}{|c|c|c|c|c|c|c|}
\hline Medium/days & $\%$ Reduced & $\begin{array}{l}\mathrm{Fe}_{\text {(tot) }}^{2+} \\
(\mathrm{mM})\end{array}$ & $\begin{array}{l}\mathrm{Fe}_{(\mathrm{aq})}^{2+} \\
(\mathrm{mM})\end{array}$ & $\begin{array}{c}\mathrm{Fe}_{\text {(sorb) }}^{2+}{ }^{\mathrm{a}} \\
(\%)\end{array}$ & $\begin{array}{c}R_{\mathrm{i}}^{\mathrm{b}} \\
(\mathrm{mM} / \mathrm{D})\end{array}$ & $\begin{array}{c}\mathrm{K}_{1}^{\mathrm{c}} \\
\left(\mathrm{d}^{-1}\right)\end{array}$ \\
\hline \multicolumn{7}{|l|}{ Natural goethite } \\
\hline PIPES/41 d & 8.8 & 4.4 & 1.8 & 59 & 1.4 & 0.3 \\
\hline $\mathrm{HCO}_{3}^{-} / 22 \mathrm{~d}$ & 9.2 & 4.6 & 1.0 & 78 & 1.0 & 0.2 \\
\hline PIPES/AQDS/33 d & 14.8 & 7.4 & 2.0 & 73 & 13.1 & 2.1 \\
\hline $\mathrm{HCO}_{3}^{-} / \mathrm{AQDS} / 33 \mathrm{~d}$ & 14.8 & 7.4 & 1.8 & 76 & 11.3 & 1.5 \\
\hline \multicolumn{7}{|l|}{ MSA goethite } \\
\hline $\mathrm{HCO}_{3}^{-}$ & 12.2 & 6.1 & 4.3 & 30 & 0.6 & 0.1 \\
\hline
\end{tabular}

\subsubsection{MSA goethite}

The bioreduction of MSA goethite was measured in $\mathrm{HCO}_{3}^{-}$ buffer without AQDS using organism and e-donor concentrations that were comparable to those used for the natural goethite. Kinetic data for the generation of biotic Fe(II) (total, aqueous) were obtained that were similar to those for the Eatontown goethite (data not shown). The total Fe(II) data were fitted to the first-order kinetic model to allow comparison of the resulting kinetic parameters with those derived for the natural goethite reduced in $\mathrm{HCO}_{3}^{-}$buffer without AQDS. The fractional reduction of MSA goethite was higher than that of the Eatontown goethite; $6.1 \mathrm{mM}(12.2 \%)$ vs. $4.6 \mathrm{mM}(9.2 \%)$ (Table 1), respectively. However, the initial rate of reduction $\left(R_{\mathrm{i}}\right)$ and the first-order rate constant $(\mathrm{k})$ were approximately $50 \%$ of that observed for the natural goethite. The most significant difference was the $\mathrm{Fe}_{(\text {aq) }}^{2+}$ concentration that accumulated more rapidly and was 4.4 times higher than that of natural goethite (Table 1).

\subsection{Characterization of the Bioreduced 0.2 to $2 \mu \mathrm{m}$ Fraction}

\subsubsection{Powder X-ray diffraction}

We had speculated that the bacteria might selectively target more easily reducible Fe(III) oxides, possibly those of smaller size or lower $\mathrm{Al}$ content, and that changes in the $\mathrm{d}_{111}$ and $\mathrm{MCD}_{111}$ of goethite, which are sensitive to these factors, might be evident. However, the diffractograms obtained after bioreduction were similar to the unreduced patterns and there was no apparent change in the $\mathrm{d}_{111}$ spacings or $\mathrm{MCD}_{111}$ (e.g., Fig. 6 for one of the most highly reduced samples). Biogenic phases (e.g., siderite) were also not evident by XRD (not shown).

\subsection{2. Мӧssbauer spectroscopy}

The RT Mössbauer spectra of the bioreduced samples displayed minor new peaks at $\sim 2.2 \mathrm{~mm} / \mathrm{s}$ (asterisks in Fig. 7). The intensity of these peaks was higher when AQDS was present. The DIRB activity affected the asymmetry of the central doublet. The intensity of the low-energy peak of the doublet at $\sim 0.2 \mathrm{~mm} / \mathrm{s}$ increased as the peaks at $2.2 \mathrm{~mm} / \mathrm{s}$ increased. Low-temperature measurements were carried out on samples with the greatest fractional reduction to characterize the bi- omineralization products and to identify changes to the residual goethite (Fig. 8). A comparison of the $77 \mathrm{~K}$ spectra of bioreduced samples from the PIPES and $\mathrm{HCO}_{3}^{-}$buffers (Fig. 8a) revealed at least 3 sets of new paramagnetic doublets present in the $\mathrm{HCO}_{3}^{-}$buffered sample. The paramagnetic doublets are labeled as distinct Fe sites in Figure 8a: Fe(III)-S1, Fe(II)-S2, and $\mathrm{Fe}(\mathrm{II})-\mathrm{S} 3$. Modeling was not performed on these spectra because their small mass content precluded unambiguous fit. The paramagnetic doublets present at $77 \mathrm{~K}$ were not seen in the spectra collected at $4.2 \mathrm{~K}$ (Fig. $8 \mathrm{~b}$ ); these reappeared when the $4.2 \mathrm{~K}$ samples were rerun at $77 \mathrm{~K}$.

The $4.2 \mathrm{~K}$ spectra were modeled using the Lorentzian model to evaluate whether changes in the $\chi_{\mathrm{Al}}[\mathrm{AC} /(\mathrm{AC}+\mathrm{Fe})]$ of the goethite occurred with bioreduction. Two sextets were included in all the fits (major $\sim 95 \%$ and minor $\sim 5$ ) and good fits were obtained. An example of data fit using the Lorentzian model is shown in Figure $8 \mathrm{~b}$. The computed $B_{\mathrm{hf}}$ values of the bioreduced samples without AQDS were identical to the unreduced sample $(49.57 \pm 0.01 \mathrm{~T})$. The bioreduced samples that were reduced with AQDS exhibited slightly higher $B_{\mathrm{hf}}$ values (49.74 \pm $0.01-49.78 \pm 0.01 \mathrm{~T}$ ).

\section{DISCUSSION}

\subsection{Properties of the Sediment Goethite Fraction}

Powder XRD was used to determine the $\mathrm{Al}$ content and crystallinity of the natural goethite. The Al-goethite was crystalline with $\mathrm{MCD}_{111}$ of $\sim 24 \mathrm{~nm}$. Aluminum substitution causes a reduction in crystallite size and unit cell dimensions (Norrish and Taylor, 1961; Thiel, 1963; Bigham et al., 1978; Fysh and Clark, 1982). The decrease in $\mathrm{d}_{111}$ spacing and $\mathrm{MCD}_{111}$ (Fig. 1) indicated that the natural goethite was Al substituted. The $\chi_{\mathrm{Al}}$ of the sediment Al-goethite was calculated from the $\mathrm{d}_{111}$ spacings using the methods of Norrish and Taylor (1961) and Thiel (1963). The calculated $\chi_{\mathrm{Al}}$ value of 0.13 to 0.15 was lower than that derived from the DCB extraction, a possible effect of DCB extraction of Al from kaolinite, the major accessory mineral phase.

${ }^{57} \mathrm{Fe}$ Mössbauer spectroscopy was used as an alternate method to characterize the Al content of the natural goethite. Pure, well-crystallized goethite exhibits a sextet ( $B_{\mathrm{hf}}$ of $38.1 \mathrm{~T}$ ) at RT due to magnetic ordering (Greenwood and Gibb, 1971). Isomorphous substitution of diamagnetic $\mathrm{Al}(\mathrm{III})$ for $\mathrm{Fe}(\mathrm{III})$ in 


\section{a. without AQDS}
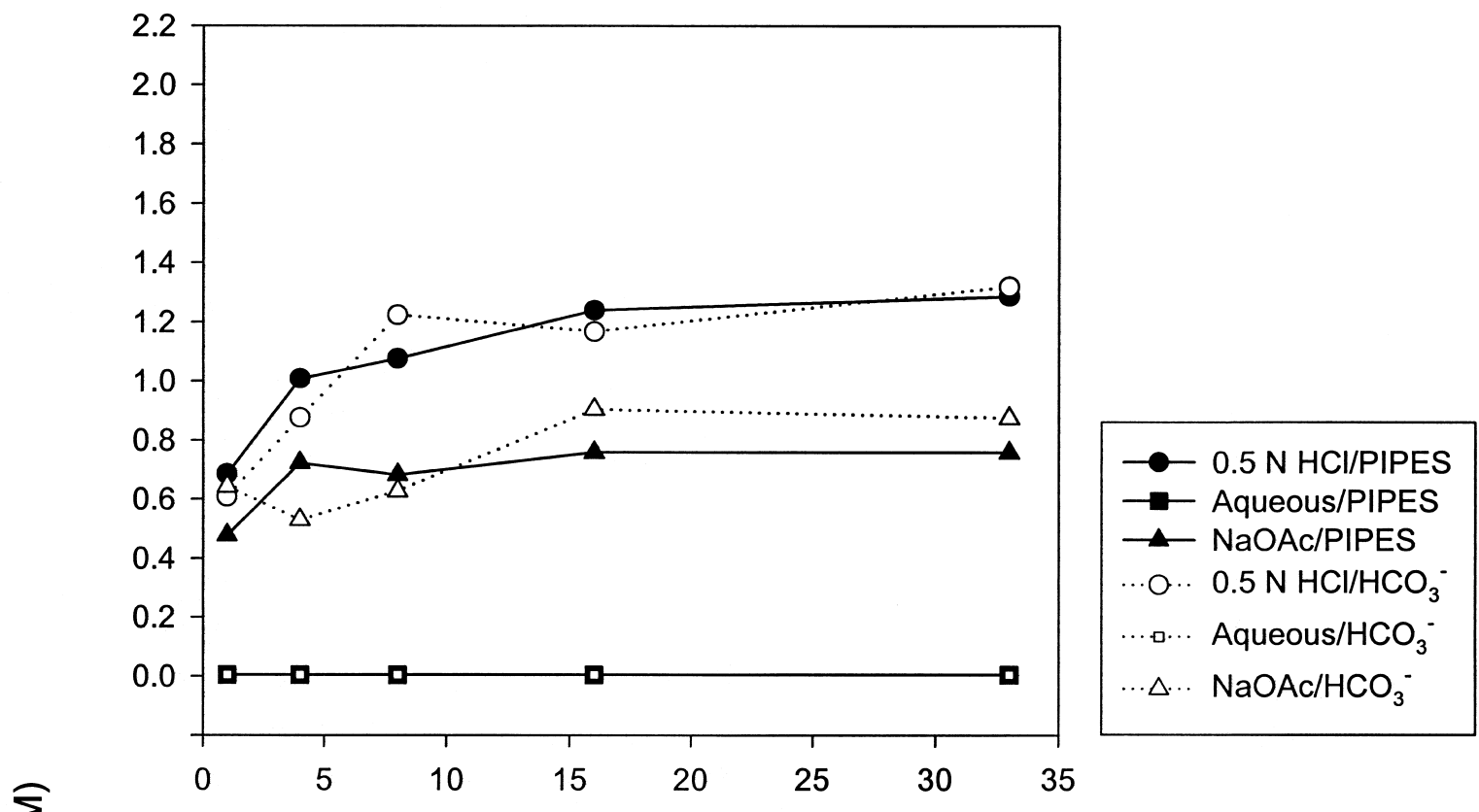

b. With AQDS

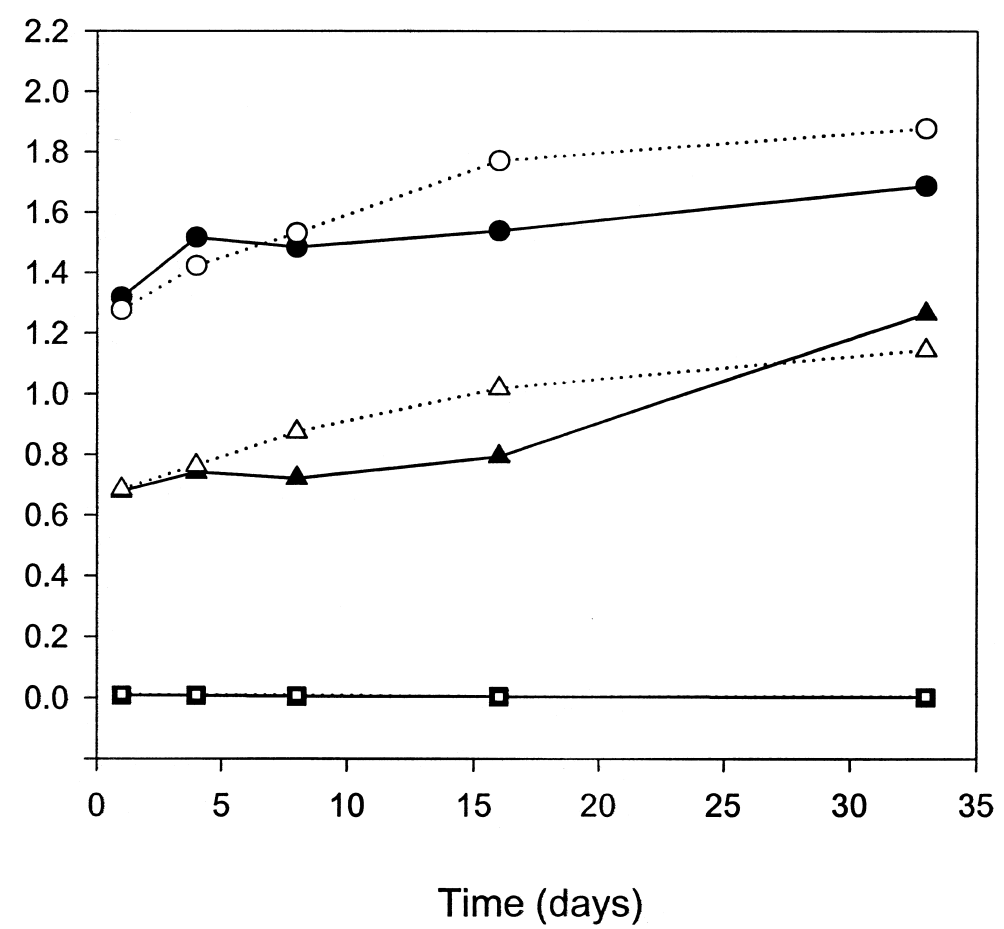
- $0.5 \mathrm{~N} \mathrm{HCl} / \mathrm{PIPES} / \mathrm{AQDS}$
$\longrightarrow$ - Aqueous/PIPES/AQDS
— NaOAc/PIPES/AQDS

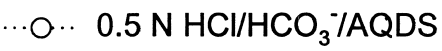
…… Aqueous/ $/ \mathrm{HCO}_{3}{ }^{-} / \mathrm{AQDS}$
$. \triangle \mathrm{NaOAC} / \mathrm{HCO}_{3}{ }^{-} / \mathrm{AQDS}$

Fig. 5. Extractable $\mathrm{Al}(\mathrm{III})(0.5 \mathrm{~N} \mathrm{HCl}, \mathrm{NaOAc})$ and $\mathrm{Al}_{(\mathrm{aq})}^{3+}$ in buffered 0.2 to $2.0 \mu \mathrm{m}$ Eatontown goethite suspensions inoculated with $\mathrm{CN} 32$ in (a) PIPES and $\mathrm{HCO}_{3}^{-}$, and (b) PIPES/AQDS and $\mathrm{HCO}_{3}^{-}$/AQDS media.

the goethite lattice lowers its magnetic ordering temperature so that a doublet is obtained at RT for an $\mathrm{Al}$ substitution of $>12 \%$ $\left(\chi_{\mathrm{Al}}>0.12\right.$; Vandenberghe et al., 1990). Therefore, the asymmetric doublet observed in the RT spectrum of the sediment size fraction was assigned to Al-goethite with $\chi_{\mathrm{Al}}>0.12$, in agreement with the XRD (Fig. 1). Al substitution also reduces the $B_{\mathrm{hf}}$, and causes a distribution of $B_{\mathrm{hf}}$ relative to pure goethite (Vandenberghe et al., 1990).

Doublet peaks were not evident in the $4.2 \mathrm{~K}$ spectrum. Lowering the measurement temperature reduces relaxation ef- 


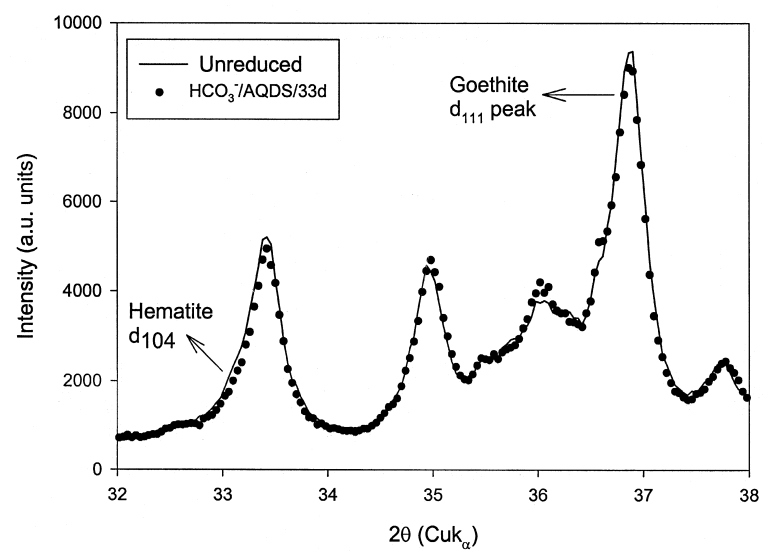

Fig. 6. Powder XRD diffractograms of unreduced and $\mathrm{HCO}_{3}^{-}$/ AQDS/33 d samples indicating Al release is congruent with Fe.

fects. Fysh and Clark (1982) proposed that the relaxation effects for Al-goethite were negligible at $4.2 \mathrm{~K}$. Murad and Schwertmann (1983), in contrast, argued that the particle size effects were not completely removed at 4.2 K. Both Fysh and Clark, and Murad and Schwertmann proposed equations to calculate the $\mathrm{Al}$ content of synthetic Al-goethites from spectra collected at $4.2 \mathrm{~K}$. Murad and Schwertmann further suggested that crystallinity information (surface area or MCD) data were essential for the calculation of $\mathrm{Al}$ content.

Lorentzian modeling of the 4.2 spectrum was performed to allow comparison with the work of Fysh and Clark (1982) and Murad and Schwertmann (1983). The $B_{\mathrm{hf}}$ values obtained for the inner $(49.55 \mathrm{~T})$ and outer sextets $(53.02 \mathrm{~T})$ were typical of Al-goethite and hematite. The $B_{\mathrm{hf}}$ value of the natural Algoethite was lower than that of crystalline, unsubstituted goethite $(50.7 \mathrm{~T})$, as expected.

The average $\chi_{\mathrm{Al}}$ values (for the inner sextet) derived from $B_{\mathrm{hf}}$ values (0.17) semiquantitatively agreed with those calculated from XRD (0.13-0.15). The small differences in $\chi_{\mathrm{Al}}$ derived from XRD and Mössbauer studies may have resulted from uncertainties in measuring $\mathrm{d}_{111}$ and $\mathrm{MCD}_{111}$ (XRD); and thickness effects, uncertain statistics, and other vagaries of the Mössbauer analysis.

Some question the application of Mössbauer spectroscopy to quantify the $\mathrm{Al}$ content of soil goethites. Vandenberghe et al. (1999) suggested that $B_{\mathrm{hf}}$ values were similarly affected by Al-substitution and crystallinity making it difficult to distinguish between their individual effects. This argument is in line with published Mössbauer analyses of nano-sized Fe(III)-oxides (Mørup, 1990; Hansen et al., 2000 and references therein), where spectra similar to Figure 3 were obtained for 10 to $20 \mathrm{~nm}$ particles. In this study, however, XRD (Fig. 1) clearly indicated that the natural goethite was Al-substituted, and, accordingly both XRD and Mössbauer spectroscopy yielded similar estimates of Al substitution.

\subsection{Comparative Bioreducibility of Natural and Synthetic Goethite}

\subsubsection{Rates and extent of bioreduction}

Despite the different aggregation status and morphology of the MSA goethite and the natural goethite (Fig. 2), their biore- duction behavior with DIRB were remarkably similar (Table 1). The equivalence in computed $\mathrm{MCD}_{111}$ for the MSA goethite $(21 \mathrm{~nm})$ and the 0.2 to $2.0 \mu \mathrm{m}$ fraction $(24 \mathrm{~nm})$ implied similarity in the fundamental crystallite size of the two goethites. We did not establish whether this similarity in crystallite coherence distance contributed to the common reduction behavior of the two phases. It was also not determined whether the large aggregates of natural goethite disaggregated in the bioreduction experiments to yield dispersed crystallites of a similar surface area to MSA. The large acceleration of reduction that accompanied the addition of AQDS (Fig. 4, Table 1) was best explained by the presence of porous goethite aggregates that allowed ingress of reduced AQDS.

\subsubsection{The role and fate of $\mathrm{Al}$}

Al-substitution inhibits both the bacterial (Bousserrhine et al., 1999) and chemical (Torrent et al., 1987; Bousserrhine et al., 1999) reductive dissolution of goethite. The inhibition may result from the adsorption of solubilized $\mathrm{Al}$, which acts to incrementally passivate the surface. Chelating agents that draw Al from the surface enhance the dissolution rate. Using fermentive bacteria that acidified the culture medium, Bousserrhine et al. (1999) observed that Al release from Al-goethite was incongruent (lower on a mole fraction basis) with that of $\mathrm{Fe}(\mathrm{II})$, and speculated that Al-oxide precipitated on the goethite surface. The bioreduction rate data for the Eatontown goethite implied that Al-substitution had little effect on its bioreduction. Whether the inhibitory effect of Al was counterbalanced by other factors, such as structural disorder, or negated by other chemical factors, such as adsorption of $\mathrm{Al}$ (III) to accessory phases, was not determined.

Al released during the bioreduction of the natural goethite was sorbed to the solid phase and was extractable by $0.5 \mathrm{~N} \mathrm{HCl}$ and $\mathrm{NaOAc}$. This behavior contrasted with that of $\mathrm{Fe}(\mathrm{II})$, where approximately 25 to $40 \%$ of the biogenic Fe(III) was released to solution (Fig. 4), and where little NaOAc extractable Fe(II) accumulated. This difference may be attributed to a greater adsorption strength of trivalent $\mathrm{Al}(\mathrm{III})$ on oxide and kaolinite surfaces. Both the $\mathrm{NaOAc}$ and $0.5 \mathrm{~N} \mathrm{HCl}$ extractable $\mathrm{Al}$ increased with incubation time (Fig. 5), indicating accumulation of bio-evolved $\mathrm{Al}$ as an adsorbed or surface precipitated phase, or combination of the two. This accumulation, combined with an indigenous sorbed Al pool implied by high initial values of $\mathrm{NaOAc}$ extractable Al, may have blocked access of Fe(II) to weaker sorption sites (e.g., exchange and edge sites on layer silicates). The reasons for different initial $0.5 \mathrm{~N} \mathrm{HCl}$ extractable $\mathrm{Al}$ concentrations in PIPES and $\mathrm{HCO}_{3}^{-}$samples, and the absence of AQDS effects on extractable Al were not explored.

The geochemical residence of biogenic $\mathrm{Al}$ (III) could not be identified because neither the $\mathrm{NaOAc}$ nor $0.5 \mathrm{~N} \mathrm{HCl}$ extractions were phase-specific. The $0.5 \mathrm{~N} \mathrm{HCl}$ extraction displaces weakly and strongly adsorbed inorganic cations on oxides and clays; and dissolves acid-soluble ferrous iron phases such as siderite, fine-grained magnetite, and green rust (Fredrickson et al., 1998), and fine-grained Al(III) oxides (Girvin et al., 1996). It will also dissolve some $\mathrm{Al}(\mathrm{III})$ from fine-grained kaolinite, which is a component of the Eatontown sediment. The NaOAc extraction displaces exchangeable metals on clays and weak to moderately adsorbed metals on oxides (Tessier et al., 1979). It 


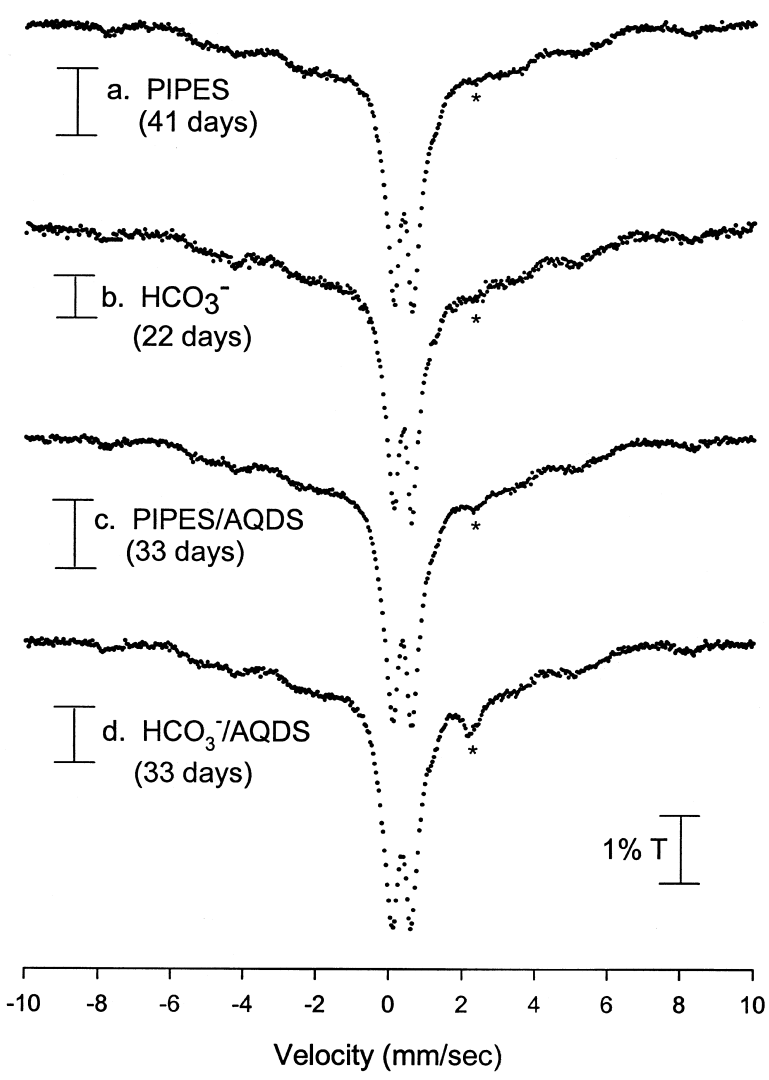

Fig. 7. Room-temperature Mössbauer spectra of bioreduced samples revealing formation of $\mathrm{Fe}(\mathrm{II})$ (asterisks in the figure): (a) PIPES/41 d, (b) $\mathrm{HCO}_{3}^{-} / 22 \mathrm{~d}$, (c) PIPES/AQDS/33 d, and (d) $\mathrm{HCO}_{3}^{-} / \mathrm{AQDS} / 33 \mathrm{~d}$.

will also dissolve carbonates although siderite is not particularly vulnerable (Hodgson, 1960; Heron et al., 1994). However, because the amount of $\mathrm{NaOAc}$ extractable $\mathrm{Al}$ was approximately $65 \%$ of that extractable by $0.5 \mathrm{~N} \mathrm{HCl}$ (Fig. 5), we may conclude that a significant fraction of the biogenic Al was weakly adsorbed to accessory mineral surfaces in the sediment, with kaolinite being the most plausible phase. A lesser amount of biogenic $\mathrm{Al}(\mathrm{III})$ (e.g., $<35 \%$ ) may have precipitated as an oxide on the residual Al-goethite surface as proposed by Bousserrhine et al. (1999).

\subsection{Biomineralization}

\subsubsection{Biomineralization products}

XRD peaks due to $\mathrm{Fe}(\mathrm{II})$ minerals were not evident in the bioreduced samples. If there was any biogenic Fe(II) mineral formation, the mass content was small (less than $5 \mathrm{wt} \%$ ). In contrast, biomineralization was evident in the RT Mössbauer spectra of all the bioreduced samples (Fig. 7). Minor peaks at $\sim 2.2 \mathrm{~mm} / \mathrm{s}$ (asterisks in Fig. 7) implied the formation of Fe(II) solids. High-energy components of the paramagnetic doublet of $\mathrm{Fe}(\mathrm{II})_{\text {oct. }}$ sites (e.g., siderite, $\mathrm{FeCO}_{3}$; green rusts, etc.) exhibit peaks in this region (Ono and Ito, 1964; Kundig et al., 1972; Sawicki and Brown, 1998; Trolard et al., 1997; Koch, 1998). Peaks at $\sim 2.2 \mathrm{~mm} / \mathrm{s}$ were prominent in samples that were incubated with AQDS for longer times (Fig. 7c,d) where $~ 10 \%$ of the $\mathrm{Fe}$ (III) pool was reduced. Fe(II) formation was also evident in samples without AQDS by the decrease in the asymmetry of the central doublet compared to the unreduced sample. The low-energy component of Fe(II) was not resolved from the inner peak of the asymmetric doublet and its mineralogic identity could not be established.

A comparison of the RT spectra of the bioreduced samples (Fig. 7) with an unreduced one spiked with $5 \pm 0.5$ wt.\% siderite $[\mathrm{Fe}(\mathrm{II}) / \mathrm{Fe}$-total $=0.11 \pm 0.01]$ (Fig. 9) indicated that a fraction of the $\mathrm{HCl}$-extractable $\mathrm{Fe}$ (II) was associated with $\mathrm{Fe}$ (II) solids in all the samples. One such comparison is shown in Figure 9 where RT Mössbauer data are presented for the 33 $\mathrm{d} / \mathrm{AQDS} / \mathrm{HCO}_{3}^{-}$bioreduced material that had the same $\mathrm{Fe}(\mathrm{II}) /$ Fe-total ratio as the siderite spiked sample. The lowered intensity of the $\sim 2.2 \mathrm{~mm} / \mathrm{s}$ peak indicated that $\sim 40$ to $50 \%$ of the $\mathrm{HCl}$-extractable $\mathrm{Fe}(\mathrm{II})$ was not incorporated into $\mathrm{Fe}(\mathrm{II})$ solid phases, and was possibly adsorbed onto residual Al-goethite, accessory mineral phases, or bacterial surfaces. This adsorbed $\mathrm{Fe}(\mathrm{II})$ was invisible to Mössbauer spectroscopy.

Low-temperature Mössbauer measurements (77 K, $4.2 \mathrm{~K}$ ) were performed to characterize the $\mathrm{Fe}(\mathrm{II})$ compounds in the bioreduced sediment (Fig. 8). Small doublets due to Fe(II) compounds were evident in all the samples. These, however,

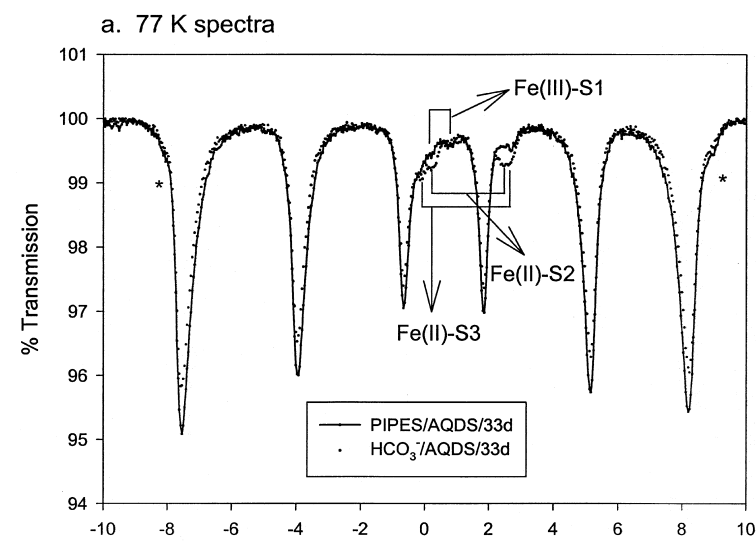

b. $4.2 \mathrm{~K}$ spectra $\left(\mathrm{HCO}_{3}{ }^{-} / \mathrm{AQDS} / 33 \mathrm{~d}\right)$

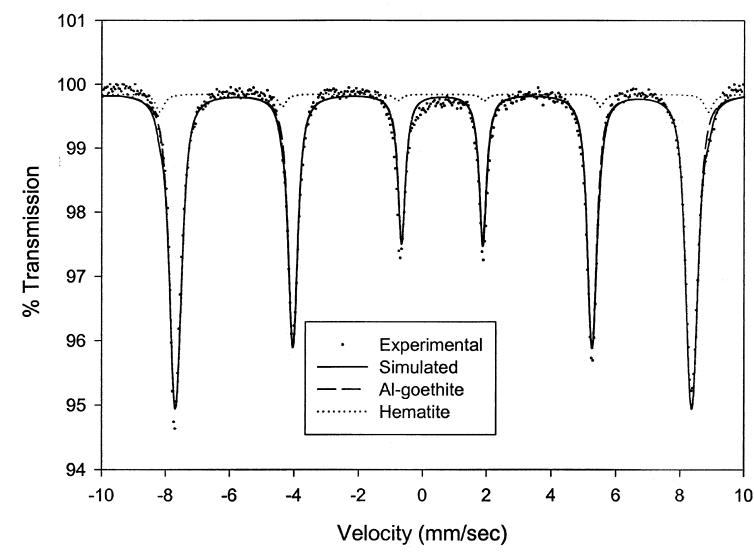

Fig. 8. (a) $77 \mathrm{~K}$ Mössbauer spectra of samples bioreduced for $33 \mathrm{~d}$ in presence of AQDS revealing peaks due to biominerals: $\mathrm{Fe}(\mathrm{III})-\mathrm{S} 1$ and $\mathrm{Fe}(\mathrm{II})-\mathrm{S} 2$ peaks due to green rust-like compound, and $\mathrm{Fe}(\mathrm{II})-\mathrm{S} 3$ peaks due to siderite and (b) $4.2 \mathrm{~K}$ spectra (experimental and simulated) of $\mathrm{HCO}_{3}^{-} / \mathrm{AQDS} / 33 \mathrm{~d}$ bioreduced sample. 


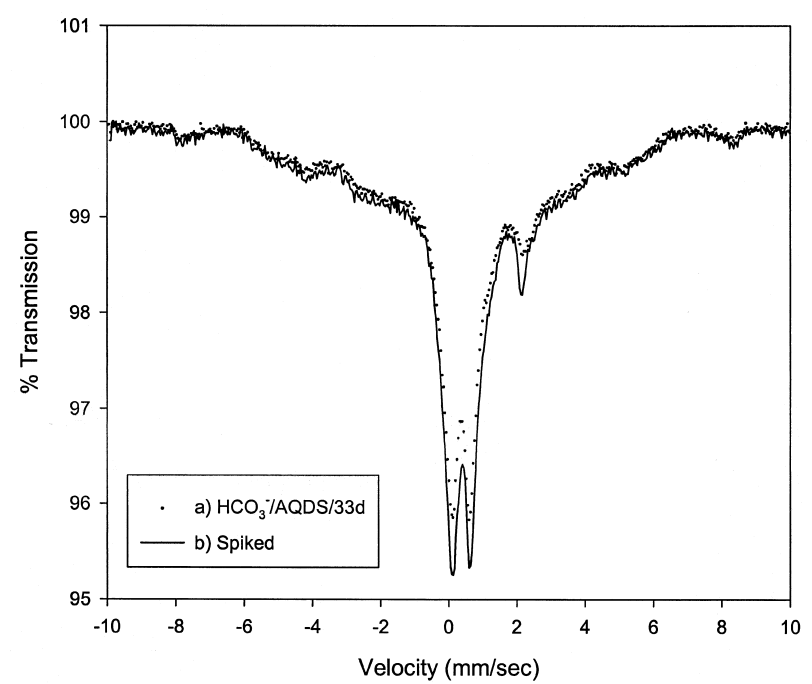

Fig. 9. Room-temperature Mössbauer spectra of (a) 0.2 to $2.0 \mu \mathrm{m}$ fraction spiked with siderite, and (b) 0.2 to $2.0 \mu \mathrm{m}$ fraction bioreduced for $33 \mathrm{~d}$ with $\mathrm{AQDS}$ in $\mathrm{HCO}_{3}^{-}$buffer, indicating that only a fraction of $0.5 \mathrm{~N} \mathrm{HCl}$ extracted $\mathrm{Fe}(\mathrm{II})$ is biomineralized.

were best resolved in the $\mathrm{HCO}_{3}^{-} / \mathrm{AQDS} / 33 \mathrm{~d}$ samples (Fig. 8a, $77 \mathrm{~K}$ ) where the extent of bioreduction was greatest. Green rust (S1 and S2 sites) and siderite (S3 site) were the most probable $\mathrm{Fe}(\mathrm{II})$ phases contributing these peaks. We were surprised to see these peaks disappear at $4.2 \mathrm{~K}$ (Fig. 8b), because siderite and green rust exhibit combined magnetic dipole and quadrupole-split patterns at 4.2 K (Kundig et al., 1972; Sawicki and Brown, 1988; Refait et al., 1998) that should have been evident if sufficient masses were present. These peaks, however, reappeared upon thawing to $77 \mathrm{~K}$, indicating that at $4.2 \mathrm{~K}$ the peaks were buried in the baseline.

\subsubsection{Al content of the residual goethite}

$\mathrm{X}$-ray analysis of goethite in the bioreduced sediments indicated that the $d_{111}$ spacings and $M C D_{111}$ were not changed by DIRB activity (Fig. 4). Al release from the natural goethite therefore appeared congruent (same on a mole fraction basis) with that of $\mathrm{Fe}$ (II). The $B_{\mathrm{hf}}$ values of the residual goethite in the bioreduced samples without AQDS, as determined by Mössbauer spectroscopy, showed little change from the starting material, indicating constancy in $\chi_{\mathrm{Al}}$. In contrast and without apparent explanation, the $\chi_{\mathrm{Al}}$ calculated from the $B_{\mathrm{hf}}$ values of the bioreduced samples with AQDS indicated that Al content of the residual goethite was decreased upon reduction. $B_{\mathrm{hf}}$ values of goethite were found to decrease upon $\mathrm{Si}$ and $\mathrm{P}$ sorption (Johnston and Norrish, 1981), and such affects may be relevant here.

\subsubsection{Extent and controls on ferrous iron precipitates}

We have observed the formation of ferrous iron biomineralization products in previous studies of the reductive dissolution of ferrihydrite, goethite, and hematite by strain CN32. These phases have included magnetite, siderite, vivianite, and green rust when ferrihydrite was used as an electron acceptor (Fredrickson et al., 1998), and siderite and vivianite when hematite and goethite were used as electron acceptors (Zachara et al., 1998). Here, little biomineralization was observed upon reduction of an Al-containing goethite in subsurface sediment. We also observed little biomineralization in a previous survey study of the reduction of sedimentary crystalline Fe(III) oxides (Zachara et al., 1998) that included the goethite-enriched Eatontown sediment studied here, as well as three other materials.

Whereas the formation of siderite through bacterial activity is widely reported (Postma, 1981; Mortimer and Coleman, $1997 \mathrm{a}$, b), biogenic green rust is less common. Green rust occurs frequently as a corrosion product of steel (Stampfl, 1969; Abdelmoula et al., 1996), and has been identified as a minor phase in hydromorphic soils (Trolard et al., 1997; Genin et al., 1998) and anoxic sediments (Genin et al., 1998) where seasonal, dissimilatory iron reduction occurs. The conditions favoring the biogenic formation of green rust are not well understood. We have observed the biogenic formation of green rust as a primary product of the reduction of 2-line ferrihydrite by CN32 under only one specific condition: in PIPES buffer with $4 \mathrm{mM} \mathrm{PO}_{4}^{3-}$ and $0.1 \mathrm{mM}$ AQDS present (Fredrickson et al., 1998). Genin et al. (1998) reported green rust as a product of the bacterial corrosion of steel.

Biomineralization in the Eatontown sediment was apparently limited by both ferrous iron supply and other chemical factors. The total extent of reduction [e.g., Fe(II) flux] was lower in the Eatontown sediment (particularly in AQDS samples) than observed in synthetic oxide suspensions (Zachara et al., 1998; Zachara et al., 1999). Approximately 4.5 and $7.4 \mathrm{mM} \mathrm{Fe(II)}$ was evolved in the Eatontown sediment in the absence and presence of AQDS (Table 1), as compared to 5 to $20 \mathrm{mM}$ in goethite suspensions where ferrous iron mineralization was significant. This lower ferrous iron concentration (in AQDS reduced samples) was further attenuated by adsorption to accessory mineral phases including kaolinite that reduced aqueous concentrations and activity. Reduced ferrous iron production, combined with the effects of adsorption explains why detectable biomineralization was only noted in the treatment with the largest amount of reduction $\left(\mathrm{HCO}_{3}^{-} / \mathrm{AQDS}\right.$, Fig. 8). Biomineralization is more significant in single-phase oxide (pure oxides) suspensions because $\mathrm{Fe}_{(\mathrm{aq})}^{2+}$ concentrations increase to high levels after the surfaces of the bacteria and residual $\mathrm{Fe}$ (III) oxide become $\mathrm{Fe}(\mathrm{II})$ saturated.

The suspension $\mathrm{pH}$ may have also have been important in preventing the necessary extent of supersaturation for nucleation and precipitation. The $\mathrm{pH}$ of the incubated subsurface material suspensions were generally lower than that observed for specimen oxides as a result of residual exchangeable acidity in the weathered, Atlantic Coastal Plain sediment. The final $\mathrm{pH}$ ranged between 6.75 without AQDS up to a maximum of 7.15 with AQDS. The final $\mathrm{pH}$ values of reduced, synthetic Fe(III) oxide suspensions are typically higher (Fredrickson et al., 1998; Zachara et al., 1998). The solubilities of both siderite and green rust are strongly $\mathrm{pH}$-dependent, increasing with decreasing pH (Bruno et al., 1992; Genin et al., 1998). The computed ion activity products for these two phases (assuming the formation of carbonate green rust and thermodynamic data from the above two sources) were below saturation in the PIPES, $\mathrm{HCO}_{3}^{-}$, and PIPES/AQDS treatments at termination of the reduction experiment. They were, however, above saturation in 
the $\mathrm{HCO}_{3}^{-} / \mathrm{AQDS}$ treatment consistent with the noted occurrence of small potential concentrations of these phases.

\section{CONCLUSIONS}

An Al-substituted goethite $\left(\chi_{\mathrm{Al}} \approx 0.15\right)$ in Pleistocene age Atlantic Coastal Plain sediment was partially reduced by $S$. putrefaciens (9-15\%). The observance of similar XRD and Mössbauer parameters for the natural goethite in the pristine and bioreduced sediment fraction indicated that the bacteria were not selectively accessing (reducing) a subfraction of the $\mathrm{Fe}(\mathrm{III})$ oxide. The release of $\mathrm{Al}$ from the natural goethite was congruent with that of $\mathrm{Fe}(\mathrm{II})$. The first-order reduction kinetics of the sedimentary Al-goethite were 2 times faster than a synthetic, pure goethite under comparable culture conditions. As a general observation, however, the reduction behavior of the natural goethite was remarkably comparable to synthetic goethite, in spite of differences in morphology and other properties of the two materials. The Al content of the natural goethite had no apparent impact on its reducibility in terms of rate or extent. The bioevolved $\mathrm{Al}$ (III) was strongly sorbed by the residual mineral fraction or bacteria. Over the range of conditions studied, the sorbed $\mathrm{Al}(\mathrm{III})$ did not passivate or inhibit the reduction process, possibly because it adsorbed or precipitated at locations that were spatially distinct from those of active reduction. From these observations, albeit limited, we conclude that Al substitution will have minimal influence on the bioreducibility of $\mathrm{Fe}$ (III) oxides in subsurface sediments. Unknown is whether this apparent lack of influence of $\mathrm{Al}$ substitution will continue at higher levels of $\mathrm{Fe}(\mathrm{III})$ oxide reduction (e.g., $>25 \%$ ).

Mössbauer spectroscopy was used to characterize biomineralization products of Al-goethite reduction. A fraction of the $\mathrm{HCl}$-extractable or sorbed $\mathrm{Fe}(\mathrm{II})$ pool was apparently precipitated as $\mathrm{Fe}$ (II) solid phases, but their precise identification was prevented by low mass content. The Mössbauer peak positions and their response to temperature were consistent with the presence of siderite or green rust. Adsorption of biogenic Fe(II) to bacteria and accessory mineral surfaces appeared to limit biomineralization in these studies by suppressing mineral supersaturation. Apparently, the saturation density of $\mathrm{Fe}(\mathrm{II})$ adsorption sites must be exceeded before significant biomineralization occurs. Why the bioreduction of goethite ceased when significant e-donor (lactate) and e-acceptor (Al-goethite) remained, and before Fe(II) sorption sites were exhausted, is an important question posed by this work. The observance of siderite and green rust in sediments and soils experiencing dissimilatory iron reduction may indicate difference in the Fe(III) oxide source term (e.g., ferrihydrite instead of goethite) or the participation of as yet undetermined phenomena that allow the greater fractional reduction of crystalline $\mathrm{Fe}(\mathrm{III})$ oxides.

Acknowledgments-This research was supported by the Natural and Accelerated Bioremediation Research Program (NABIR), Office of Biologic and Environmental Research, U.S. Department of Energy (DOE). Pacific Northwest National Laboratory is operated for the DOE by Battelle Memorial Institute under Contract DE-AC06 to 76RLO 1830. We thank associate editor, Nathaniel E. Ostrom and anonymous reviewers for their help in improving the manuscript.

\section{REFERENCES}

Abdelmoula M., Refait Ph., Drissi S. J., Mihe J. O., and Genin J.-M. R. (1996) Conversion electron Mössbauer spectroscopy and X-ray diffraction studies of the formation of carbonate-containing green rust one by corrosion of metallic iron in $\mathrm{NaHCO}_{3}$ and $\left(\mathrm{NaHCO}_{3}+\mathrm{NaCl}\right)$ solutions. Corr. Sci. 38, 623-633.

Arnold R. G., Olson T. M., and Hoffman M. R. (1986) Kinetics and mechanism of dissimilative Fe(III) reduction by Pseudomonas sp. 200. Biotech. Bioengineer. 28, 1657-1671.

Bigham J. M., Golden D. C., Bowen L. H., Boul S. W., and Weed S. B. (1978) Iron oxide mineralogy of well-drained ultisols and oxisols: I. Characterization of iron oxides in soil clays by Mössbauer spectroscopy, X-ray diffractometry, and selected chemical techniques. Soil. Sci. Soc. Am. J. 42, 816-825.

Bousserrhine N. Gasser U. G., Jeanroy E., and Berthelin J. (1999) Bacterial and chemical reductive dissolution of $\mathrm{Mn}-, \mathrm{Co}-, \mathrm{Cr}-$, and Al-substituted goethites. Geomicrobiology J. 16, 245-258.

Bruno J., Wersin P., and Stumm W. (1992) On the influence of carbonate in mineral dissolution: II. The solubility of $\mathrm{FeCO}_{3}$ (s) at $25^{\circ} \mathrm{C}$ and $1 \mathrm{~atm}$ total pressure. Geochim. Cosmochim. Acta 56, $1149-1155$

Chao T. T. and Zhou L. (1983) Extraction techniques for selective dissolution of amorphous iron oxides from soils and sediments. Soil Sci. Soc. Am. J. 47, 225-232.

Chapelle F. H. (1993) Ground-Water Microbiology and Geochemistry. Wiley, New York.

Cornell R. M. and Schwertmann U. (1996) The Iron Oxides. Weinheim, VCH Verlag (Chap. 3).

Dong H., Fredrickson J. K., Kennedy D. W., Zachara J. M., Kukkadapu R. K., and Onstott T. C. (2000). Mineral transformation associated with the microbial reduction of magnetite. Chem. Geology 169, 299-318.

Fey M. V. and LeRoux. J. (1977) Properties and quantitative estimation of poorly crystalline components in sesquioxide soil clays. Clays Clay Miner. 25, 285-294.

Fredrickson J. K., Zachara J. M., Kennedy D. W., Dong H., Onstott T. C., Hinman N. W., and Li S. (1998) Biogenic Fe mineralization accompanying the dissimilatory reduction of hydrous ferric oxide by a ground water bacterium.Geochim. Cosmochim. Acta 62, 32393257.

Fysh S. A. and Clark P. E. (1982) Aluminous goethite: A Mössbauer study. Phys. Chem. Miner. 8, 180-187.

Genin J.-M. R., Refait Ph., Simon L., and Drissi S. H. (1998) Preparation and $E_{\mathrm{h}}-\mathrm{pH}$ diagrams of $\mathrm{Fe}(\mathrm{II})-\mathrm{Fe}(\mathrm{III})$ green rust compounds; hyperfine interaction characteristics and stoichiometry of hydroxychloride, -sulphate and -carbonate. Hyper. Inter. 111, 313-318.

Girvin D. C., Gassman P. L., and Bolton H. Jr. (1996) Adsorption of nitrilotriacetate (NTA), Co, and CoNTA by gibbsite. Clays Clay Miner. 44, 757-768.

Greenwood N. N. and Gibb T. C. (1971) Mössbauer Spectroscopy. Chapman and Hall, London.

Hansen M. F., Koch C. B., and Mørup S. (2000). Magnetic dynamics of weakly and strongly interacting hematite nanoparticles. Phys. Rev. B. 62, 1124-1135.

Heron G., Crouzet C., Bourg A. C. M., and Christensen T. H. (1994) Speciation of $\mathrm{Fe}$ (II) and $\mathrm{Fe}$ (III) in contaminated aquifer sediments using chemical extraction techniques. Environ. Sci. Technol. 28, $1698-1705$.

Hodgson J. F. (1960) Cobalt reactions with montmorillonite. Soil. Sci. Soc. Am. Proc. 24, 165-168.

Johnston J. H. and Norrish K. (1981) Aust. J. Soil. Res. 19, 231.

Koch C. B. (1998) Structures and properties of anionic clay minerals. Hyperfine Interactions 117, 131-157.

Kundig W., Denison A. B., and Ruegsegger P. (1972) Anisotropy of the recoil free factor in magnetic layer structures. Phys. Lett. 42A, 199-201.

Liu C., Kota S., Zachara J. M., Fredrickson J. K., and Brinkman C. K. (2001) Kinetic analysis of the bacterial reduction of goethite. Environ. Sci. Technol. 35, 2482-2490.

Lovley D. R. and Philips E. J. P. (1986) Availability of ferric Fe for microbial reduction in bottom sediments of the freshwater tidal Potomac River. Appl. Environ. Microbiol. 52, 751-757. 
Lovley D. R., Chapelle F. H., and Philips E. J. P. (1990) Fe(III) reducing bacteria in deeply buried sediments of Atlantic coastal plan. Geology 18, 954-957.

Mehra O. P. and Jackson M. L. (1960) Iron oxide removal from soils and clays by a dithionite-citrate system buffered with sodium bicarbonate. Clays Clay Miner. 7, 317-327.

Mortimer R. J. G. and Coleman M. L. (1997a) Microbial influence on the isotopic composition of diagenetic siderite. Geochim. Cosmochim. Acta 61, 1705-1711.

Mortimer R. J. G. and Coleman M. L. (1997b) Effect of bacteria on the elemental composition of early diagenetic siderite: Implications for palaeoenvironmental interpretations. Sedimentology 44, 759-765.

Mørup S. (1990) Mössbauer effect in small particles. Hyperfine Interactions. 60, 959-974.

Murad E. and Schwertmann U. (1983) The influence of aluminum substitution and crystallinity on the Mössbauer spectra of goethite. Clay Miner. 18, 301-312.

Norrish K. and Taylor R. M. (1961) The isomorphous substitution of iron by aluminum in soil goethites. J. Soil Sci. 12, 294-306.

Ono K. and Ito A. (1964) Mössbauer study of magnetic properties in ferrous compounds. J. Phys. Chem. 19, 899-907.

Postma D. (1981) Formation of siderite and vivianite and the porewater composition of a recent bog sediment in Denmark. Chem. Geol. 31, 225-244.

Refait P., Charton A., and Genin, J.-M. R. (1998) Identification, composition, thermodynamic and structural properties of a pyroauritelike iron(II)-iron(III) hydroxy-oxalate green rust. Eur. J. Solid State Inorg. Chem. 35, 655-666.

Roden E. E. and Zachara J. M. (1996) Microbial reduction of crystalline iron(III) oxides: Influence of oxide surface area and potential for cell growth. Environ. Sci. Technol. 30, 1618-1628.

Sawicki J. A. and Brown D. A. (1998) Investigation of microbialmineral interactions by Mössbauer spectroscopy. Hyperfine Interactions 117, 371-382.

Schwertmann U. (1964) The differentiation of iron oxides in soil by extraction with ammonium oxalate solution.Z. Pflanzenernaehr. Dueng. Bodenk. 105, 194-202.

Schwertmann U. (1984) The influence of aluminum on iron oxides. IX. Dissolution of Al-goethites in $6 \mathrm{M} \mathrm{HCl}$. Clay Miner. 19, 9-19.

Schwertmann U. (1985) The effect of pedogenic environments on iron oxide minerals. Adv. Soil. Sci. 1, 171-200.

Schwertmann U. and Cornell R. M. (1991) Iron Oxides in the Laboratory: Preparation and Characterization. VCH Publishers, Weinheim, Germany.
Stampfl P. P. (1969) Ein Basisches Eisen-II-III-Karabonat in Rost. Corrosion Sci. 9, 185-187.

Stookey L. L. (1970) Ferrozine: A new spectrophotometric reagent for iron. Anal. Chem. 42, 779-781.

Sulzberger B., Suter C., Siffert S., Banwart S., and Stumm W. (1989) Dissolution of $\mathrm{Fe}(\mathrm{III})$ (Hydr)oxides in natural waters; laboratory assessment on the kinetics controlled by surface coordination. $\mathrm{Ma}$ rine Chem. 28, 127-144.

Tessier A., Campbell P. G. C., and Bisson M. (1979) Sequential extraction procedure for speciation of particulate trace metals. Anal. Chem. 51, 884-851.

Thiel R. (1963) Zum system $\alpha$-FeOOH- $\alpha$-AlOOH. Z Inorg. Allg. Chem. 326, 70-78.

Torrent J., Schwertmann, U., and Barron V. (1987) The reductive dissolution of synthetic goethite and hematite in dithionite. Clays Clay Miner. 40, 14-21.

Trolard F., Genin J.-M. R., Abdelmoula M., Bourrie G., Humbert B., and Herbillon A. (1997) Identification of a green rust mineral in a reductomorphic soil by Mössbauer and Raman spectroscopies. Geochim. Cosmochim. Acta 61, 1107-1111.

Urrutia M. M., Roden E. E., Fredrickson J. K., and Zachara J. M. (1998) Microbial and surface chemistry controls on reduction of synthetic Fe(III) oxide minerals by the dissimilatory iron-reducing bacterium Shewanella alga. Geomicrobiology 15, 269-291.

Urrutia M. M., Roden E. E., and Zachara J. M. (1999) Influence of aqueous and solid-phase(II) complexants on microbial reduction of crystalline iron(III) oxides. Environ. Sci. Technol. 33, 4022-4028.

Vandenberghe R. E., De Grave E., Landuydt C., and Bowen L. H. (1990) Some aspects concerning the characterization of iron oxides and hydroxides in soils and clays. Hyperfine Interactions 53, 175196.

Vandenberghe R. E., Barrero-Meneses C. A., da Costa G. M., Van San E., and De Grave E. (1999) Mössbauer characterization of oxides and (oxy)hydroxides: The present state of the art. International Congress on Applications of Mössbauer Effect, Garmisch-Partenkirchen, Germany, T6/43.

Zachara J. M., Fredrickson J. K., Li S. W., Kennedy D. W., Smith S. C., and Gassman P. L. (1998) Bacterial reduction of crystalline Fe(III) oxides in single phase suspensions and subsurface materials. Am. Mineral. 83, 1426-1443.

Zachara J. M., Smith S. C., and Fredrickson, J. K. (1999) The effect of biogenic $\mathrm{Fe}(\mathrm{II})$ on the stability and sorption of $\mathrm{Co}(\mathrm{II}) \mathrm{EDTA}^{2-}$ to goethite and a subsurface sediment. Geochim. Cosmochim. Acta 64, 1345-1362. 